\title{
Socioeconomic, Environmental, and Behavioral Determinants of Leprosy in Kediri, East Java
}

\author{
Anindita Hasniati Rahmah'), Ruben Dharmawan²), Setyo Sri Rahardjo²) \\ 1) Masters Program in Public Health, Universitas Sebelas Maret \\ 2) Faculty of Medicine, Universitas Sebelas Maret
}

\begin{abstract}
Background: Leprosy remains a major public health problem in the world, particularly in developing countries. Leprosy can be so progressive that damages skin, nerve, extremity, and eye organs of the affected patients. Cumulative incidence of leprosy amounted to 200,000 cases worldwide, with the highest incidences occuring in India, Brazil, and Indonesia. This study sought to examine the social economic, environmental, and behavioral determinants of leprosy in Kediri, East Java, using path analysis approach.

Subjects and Method: This was an analytic observational study with case control design. The study was conducted at Leprosy Hospital, Kediri, East Java, from November to December 2017. A total sample of 150 study subjects consisting of 75 leprosy patients and 75 non-diseased subjects were selected for this study by fixed disease sampling. The dependent variable was leprosy. The independent variables were personal hygiene, education, employment status, family income, dwelling density, humidity, and migration. Data on leprosy diagnosis was taken from medical record. The other data were collected by questionnaire. The data were analyzed by path analysis.

Results: The risk of leprosy increased with poorer personal hygiene $(b=-1.20 ; 95 \% \mathrm{CI}=-1.92$ to $0.49 ; \mathrm{p}=0.001)$, higher humidity $(\mathrm{b}=0.73 ; 95 \% \mathrm{CI}=0.33$ to $1.43 ; \mathrm{p}=0.040)$, and migration $(\mathrm{b}=$ $0.94 ; 95 \% \mathrm{CI}=0.14$ to $1.74 ; \mathrm{p}=0.022)$. Being employed status increased family income $(\mathrm{b}=1.41$; $95 \% \mathrm{CI}=0.72$ to $2.11 ; \mathrm{p}<0.001)$. Low family income increased the likelihood of migration $(\mathrm{b}=-14$; $95 \% \mathrm{CI}=-1.71$ to $-3.19 ; \mathrm{p}=0.007)$ and dwelling density $(\mathrm{b}=-1.02 ; 95 \% \mathrm{CI}=-1.71$ to $-0.32 ; \mathrm{p}=0.004)$. Higher education level increased the likelihood of being employed $(b=1.41 ; 95 \% \mathrm{CI}=0.72$ to 2.11 ; $\mathrm{p}<0.001)$ and better personal hygiene $(\mathrm{b}=1.15 ; 95 \% \mathrm{CI}=0.44$ to $1.85 ; \mathrm{p}=0.001)$. Dwelling density increased the likelihood of humidity $(b=4.29 ; 95 \% \mathrm{CI}=3.22$ to $5.37 ; \mathrm{p}<0.001)$.

Conclusion: Migration, higher humidity, and poorer personal hygiene directly increase the risk of leprosy. Education, employment status, family income, and dwelling density indirectly affect the risk of leprosy.
\end{abstract}

Keywords: Leprosy, social economic, environmental, personal hygiene

\section{Correspondence:}

Anindita Hasniati Rahmah. Masters Program in Public Health, Universitas Sebelas Maret, Jl. Ir. Sutami 36 A, Surakarta 57126, Central Java. Email: aninditarahma22@gmail.com.

\section{BACKGROUND}

Leprosy is still a problem for developing countries and is a major problem in the world (WHO, 2016b). New cases annually reach over 200,000 patients, mainly in India, Brazil, and Indonesia (Reibe et al., 2015). Most cases of leprosy have been reported in developing countries. Leprosy is a curable disease if detected at an early stage and early detection in order to reduce the risk of disability. Leprosy can be so progressive that it can cause damage to the skin, nerves, limbs, and eyes if not treated immediately (Alotaibi et al., 2016).

World Health Organization (2016) states that in developing countries, there are more than 1000 new cases of leprosy each year. The distribution of new leprosy in India is 127,326 representing for $60 \%$ of the total cases of new leprosy in the world. 
Journal of Epidemiology and Public Health (2018), 3(2): 253-262

https://doi.org/10.26911/jepublichealth.2018.03.02.05

Indonesia as the third country with the largest number of leprosy has 17,202 new cases representing $8 \%$ of total cases in the world. Leprosy is still a health problem in Indonesia, the problem is not only medical but extends to social, economic, cultural, security and national security issues.

In 2013, this experienced a significant decline from 18,994 cases to 16,856 cases. By 2015, there is an increase to 17,202 cases. In some provinces, the number of leprosy patients is still high. Yet the burden caused by the old disease is very large because it can cause disability. Based on Indonesia's health profile, there are 3 provinces in Indonesia with high leprosy cases of more than 1,000 cases per year, namely Central Java, West Java and Banten provinces. In these areas, there are more than 1,00o cases per year with most cases in East Java province of 3636 cases.

Based on the data from East Java Provincial Health Office, the prevalence of leprosy rate at the end of 2010 in East Java was 4653 cases or 1.64 per 10,000 population, which means that it is still above the target of $1 / 10.000$ population (Ministry of Health, 2015). Based on preliminary study conducted at RSK Kediri in the last three years, it tends to fluctuate. The incidence of leprosy cases in RSK Kediri has increased from 2014 becoming 164 cases of leprosy cases and 2015 cases were 272 cases, followed by leprosy cases in 2016 for about 312 cases. Epidemiologically, the incidence of leprosy is influenced by 3 main factors, namely disease agent factor (Mycobacterium Leprae); host factors such as personal hygiene, age and education level; and environmental factors, such as the physical, chemical, biological, and social environments.

Leprosy is present in developing countries and some sufferers come from low economic group. This causes leprosy still becoming a public health problem. The poor condition of the environment that many found in the poor is a nest for the development of bacteria that cause leprosy. Low self-hygiene behavior is also a risk factor for leprosy.

Based on the background, the author was interested to analyze the social economic, environmental, and behavioral determinants of leprosy in Kediri, East Java, using path analysis approach.

\section{SUBJECTS AND METHODS}

\section{Study Design}

This was a case control study. The target population was leprosy patients who seek for treatment at Leprosy Hospital Kediri. The study was conducted at Leprosy Hospital, Kediri, East Java from November to December 2017.

\section{Population and sample}

The case population was leprosy patients at Leprosy hospital, Kediri. While the control population was patients who do not suffer from leprosy who live in leprosy patients areas.

The sampling technique was fixed disease sampling with a sample size of 150 subjects using a ratio of 1: 1 . The number of case samples were 75 patients suffering from leprosy and control samples of 75 patients who did not suffer from leprosy.

\section{Study Variables}

The dependent variable was leprosy. The independent variables were education level, occupation, income, personal hygiene, occupancy density, air humidity and migration.

\section{Operational Definition of Variables}

Education was defined as the last level of formal education obtained until graduated by the subjects. The data were collected by questionnaires. The measurement scale was categorical. 
Family income was defined as the average income earned by parents per month in the last six months. The income consists of the income of the father and the mother (if employed) as well as the income from the main job or some freelance one. The data were collected by questionnaires. The measurement scale was continuous.

Occupation was defined as a type of daily activity conducted by study subjects to earn income, the measuring tool was a questionnaire. The data were collected by questionnaires. The measurement scale was categorical.

Migration was defined as the movement of subjects from within countries to out of the country with endemic leprosy which aims to stay $\geq 6$ months and return to the place of origin. The data were collected by questionnaires. The measurement scale was categorical.

Air humidity was defined as the percentage of the amount of water content in the air within the subject's house. The data were collected by questionnaires. The measurement scale was continuous.

The density of the dwelling was defined as the ratio of the floor area of the house to the number of family members of the research subject in one house. For simple housing, it is usually at least $8 \mathrm{~m}^{2} /$ person. The data were collected by questionnaires. The measurement scale was continuous.

Personal hygiene was defined as selfcare done by the subjects to maintain their hygiene of their hair, tooth and mouth, skin, hands and feet, and clothing. The data were collected by questionnaires. The measurement scale was continuous.

Leprosy was defined as a chronic infection that affects the skin and peripheral nerves caused by Mycobacterium leprosy. This disease is a type of granulomatous disease of the peripheral nerve and mucosa of the upper respiratory tract with an observable outer sign that is a skin lesion. The data were taken from medical record at Leprosy hospital, Kediri. The measurement scale was categorical.

\section{Data Analysis}

The data were analyzed by path analysis to determine the magnitude of the influence of variables, either the direct or indirect influences. The magnitude of the influence of independent variables (exogenous) on the dependent variable (endogenous) can be seen from the coefficient of the path, the greater the coefficient of the path will be, the greater the influence given from that variable.

Pathway analysis steps were model specification, model identification, model conformity, parameter estimation and model respesification.

\section{Research Ethics}

The research ethical clearance was granted from the Research Ethics Committee at Dr. Moewardi Hospital, Surakarta, Central Java, Indonesia. Research ethics included issues such as informed consent, anonymity, confidentiality, and ethical clearance.

\section{\begin{tabular}{lcl}
\hline \multicolumn{3}{c}{ RESULTS } \\
\hline 1. The characteristics of study
\end{tabular} subjects}

Table 1 shows that study subjects aged $<42$ years and $\geq 42$ years were equal. Most of the study subjects were female $(41,52.6 \%)$.

As many as 45 study subjects (51.1\%) in case group had low education $(<$ Senior high school).

Most of the research subjects were working in the case group (38 subjects) or $52.8 \%$ and most of the subjects in the control group did not work that is for about 41 subjects or $52.6 \%$.

Most of the study subjects in the case group had in low-income (44.4\%). In control group, most of them also had low 
Journal of Epidemiology and Public Health (2018), 3(2): 253-262

https://doi.org/10.26911/jepublichealth.2018.03.02.05

income that is for about 50 subjects or

$55.6 \%$ from all subjects.

Table 1. Characteristics of research subjects based on age, gender, occupation and education

\begin{tabular}{|c|c|c|c|c|c|}
\hline \multirow{2}{*}{ No } & \multirow{2}{*}{ Characteristics } & \multicolumn{2}{|c|}{ Case } & \multicolumn{2}{|c|}{ Control } \\
\hline & & $\mathbf{n}$ & $\%$ & $\mathbf{N}$ & $\%$ \\
\hline \multirow[t]{3}{*}{1.} & Age & & & & \\
\hline & $<42$ years & 30 & 40.5 & 44 & 59.5 \\
\hline & $\geq 42$ years & 45 & 59.2 & 31 & 40.8 \\
\hline \multirow[t]{3}{*}{2.} & Sex & & & & \\
\hline & Male & 38 & 52.8 & 34 & 47.2 \\
\hline & Female & 37 & 47.4 & 41 & 52.6 \\
\hline \multirow[t]{3}{*}{3.} & Education & & & & \\
\hline & Low & 45 & 51.1 & 43 & 48.9 \\
\hline & High & 30 & 48.4 & 32 & 51.6 \\
\hline \multirow{3}{*}{4.} & Employment & & & & \\
\hline & Not employed & 37 & 47.4 & 41 & 52.6 \\
\hline & Employed & 38 & 52.8 & 34 & 47.2 \\
\hline \multirow[t]{3}{*}{5.} & Income & & & & \\
\hline & Low & 40 & 44.4 & 50 & 55.6 \\
\hline & High & 35 & 58.3 & 25 & 41.7 \\
\hline
\end{tabular}

\section{Path Analysis Results}

The data analysis used Stata 13 program. Based on path analysis on the research results, the following results were obtained:

\section{a. Model Spesification}

Model specifications illustrated the relationship between the variables studied.
Measurable variables in this study were family income, migration, occupancy density, education level, occupation, personal hygeine, occupancy density and leprosy.

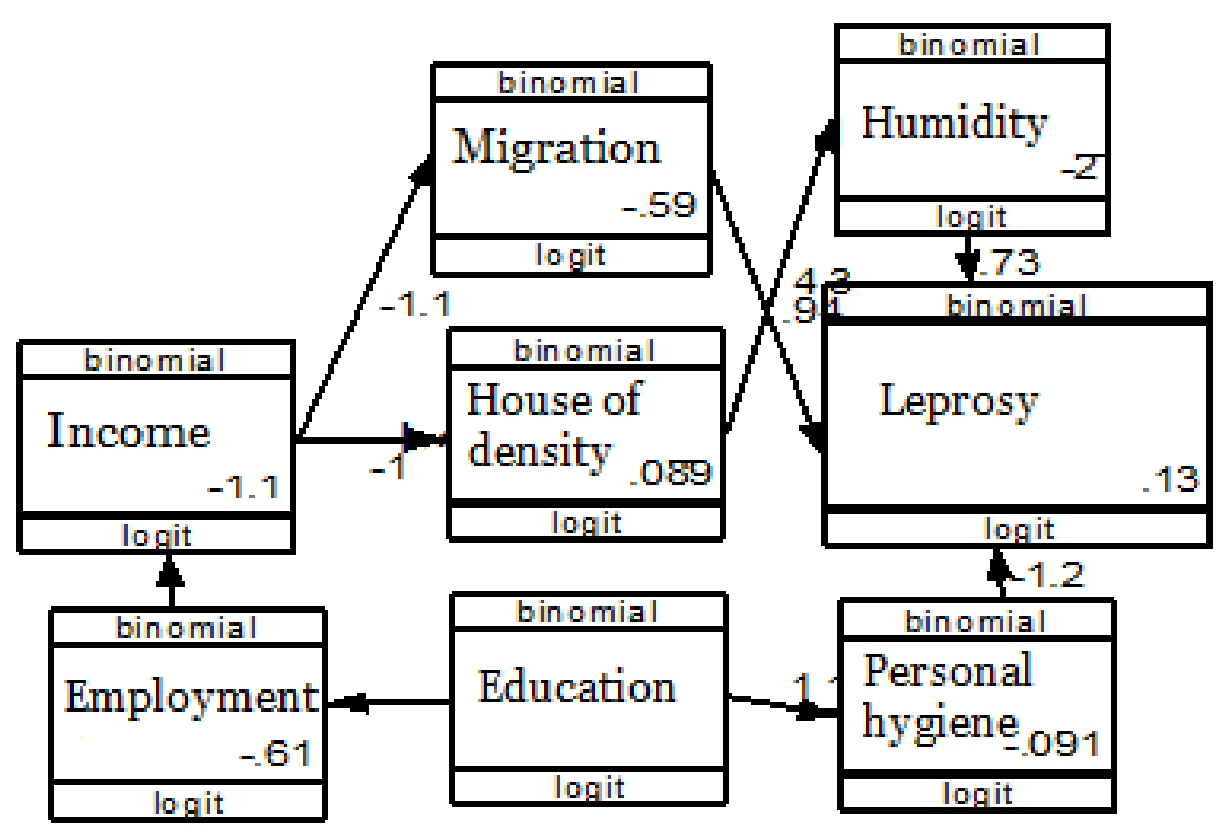

Figure 1. Structural model with the estimate of socioeconomic, environmental and behavioral determinant of leprosy event 


\section{The relationship between migra- tion and leprosy incident}

Leprosy is a public health problem with a new case. Transmission of leprosy was affected by migration. Migration can transmit the disease in endemic and nonendemic areas and has been considered as a factor in the incidence of leprosy (WHO, 2016a).

The result of this study showed that migration increased the risk of leprosy. This study was supported by Murto et al. (2013) who investigated migration as a risk factor for leprosy. Significantly, leprosy was directly related to family, household, and other family contacts. The pattern of migration in the transmission of leprosy disease in endemic areas with high mobility of population. Leprosy became a common health problem in endemic high-risk groups of leprosy transmission and was associated with leprosy.

A study by Murto (2013) analyzed the relationship between leprosy and migration in five years ago as part of a large epidemiological study that evaluated the risk factors of leprosy infection. Factors found between leprosy and migration for 5 years were due to poverty and contact with lepers. The endemic areas of disease were still there despite the efforts of national control to the disease. Challenges in controlling leprosy disease because of its long-time diagnosis and long periods of incubation.

Migration has been a risk factor of disease. Previous study in Brazil stated that migration enhanced the distribution of leprosy. This was because the migrants lived in the suburbs of Brazil. Immigrants migrated from endemic areas to non-endemic areas and live in substandard conditions which lead to leprosy transmission (Murto et al., 2013). It can be concluded that the results of this study showed that migration increased the risk of leprosy incident.

\section{The relationship between personal hygiene and leprosy incident}

Personal hygiene, especially of the hands was considered as one of the main ways to reduce the risk of transmission. Poor personal hygiene increased the prevalence of disease (Larson, 1999).

The result of this study showed that poor personal hygiene increased the risk of leprosy. This study was supported by a study done by Deodhar et al. (2003). Hygiene is an activity for health protection and disease prevention. The relationship between hygiene and epidemiology is the protection of health and disease prevention by finding the cause of disease. The environment consists of humans, such as disease or pathogens. Vectors such as mosquitoes, water and air contaminated with harmful germs. Good personal hygiene can help to prevent transmitted diseases (Deodhar, 2003).

\section{The relationship between humidity and leprosy incident}

The result of this study showed that humidity increased the risk of leprosy. This study was supported by a study of James et al (2016), which stated that humidity is used to estimate skin moisture. Humidity as a whole is the moisture in the area. After being exposured by sunlight, it decreased the humidity of the room (James et al., 2017).

Based on the descriptions above, it can be concluded that humidity increased the risk of leprosy. Thus in accordance with previous studies and existing theories.

\section{The relationship between educa- tion and employment}

The result of this study showed that educational level increased the risk of leprosy through employment. This is in 
accordance with a study by Nurhayati et al. (2017). Highly-educated people would certainly have a proper job and have a high income as well, therefore, parents with such criteria would prioritize the appropriate nutritional intake for their children and provide the best in order to support the growth and development of their children. Another case with parents who have low education, their knowledge, skills and abilities were also low. Automatically, it will lead to lack of job opportunities and the income was low, therefore, it would be difficult for them to fulfill the nutrients of their children. The immune system of the family was low and became susceptible to disease. In addition, education also affected the knowledge about the importance of health for themselves and the family. Therefore, parental education, parental employment, and parental income were a continuous thing that affect both poor nutritional status and health services (Kurniasari and Nurhayati, 2017).

\section{The relationship between educa- tion and personal hygiene}

The result of this study showed that educational level increased the risk of leprosy through poor personal hygiene. This was in accordance with a study by Khatoon (2017), which stated that poor personal hygiene can lead to transmitted diseases in developing countries (Khatoon et al., 2017).

\section{The relationship between employ- ment and income}

Family income is the income earned by family members which is used to fulfill the needs of family in their daily life. The family income can be either money or goods paid by the company, office, or employer (Central Bureau of Statistics, 2013). The result of this study showed that most of the subjects have low family income (<Rp. 2.200.000).
This study was supported by a study of Kurniawati et al. (2017) which stated that employment would affect the income. Low level of education would lead to the difficulty for the community to find decent work. Educational factors were highly correlated with employment. Decent work would also affect family income. Women who have participation in work would have a great effect on family income. If the employment opportunities in the region were high, then women would choose to pursue their career (Kurniawati et al., 2017).

\section{The relationship between income and migration}

The result of this study showed that there was a relationship between income and leprosy through migration. This study was supported by a study of Black (2005), which stated that international and national migrations can affect the income. However, international migration was an activity that carried a significant risk of disease transmission. People who migrate were mostly from the middle to lower class in order to improve their family finance. It can be seen from the enhancement of money transfer from one country to another. Productive age was the most migrated age (Black et al., 2015).

\section{The relationship between family income and dwelling density}

The result of this study showed that there was a relationship between family income and leprosy through dwelling density. This study was supported by James et al (2017) who stated that the density of mixed land use and road connectivity has generally been associated with family income. The higher the income of a person, then they would try to improve their quality of life including the dwelling. They would enlarge their dwelling according to the number of family members. Qualitative studies report- 
ed that the dwelling was considered as an important determinant of health. Environmental quality such as dense dwelling would lead to the transmission of transmitted diseases (James et al., 2017).

\section{The relationship between dwelling density and humidity}

The result of this study showed that there was a relationship between dwelling density and leprosy through humidity. This study was supported by Miranda et al. (2014) who stated that air quality is an increasing problem in today's world. The number of people, buildings or dwellings can change the air quality. The relative humidity over the normal indoor temperature range (6680 degrees Fahrenheit) either directly or indirectly affected the health problems. The results verified the hypothesis that relative humidity levels had a significant effect on the environment and could be associated with health problems. The density of the dwelling would affect the humidity (Miranda et al., 2014).

Based on the description above, it can be concluded that the leprosy incident was directly affected by migration, humidity, and personal hygiene. In addition, leprosy incident was indirectly affected by educational level, employment, family income, and dwelling density.

\section{REFERENCES}

Alotaibi MH, Bahammam SA, Ur Rahman S, Bahnassy AA, Hassan IS, Alothman AF And Alkayal AM (2016). The Demographic And Clinical Characteristics Of Leprosy In Saudi Arabia, Journal Of Infection And Public Health, 9(5): 611-617. Doi: 10.1016/J.Jiph.2015.12.015.

Deodhar NS (2003). Epidemiological Perspective Of Domestic And Personal Hygiene In India, International
Journal Of Environmental Health Research, 13(1). Doi: 10.1080/0960312031000102796.

James P, Hart JE, Banay RF, Laden F, Signorello LB (2017). Built Environment And Depression In Low-Income African Americans And Whites, American Journal Of Preventive Medicine, 52(1): 74-84. Doi: 10.1016/J.Amepre.2016.08.022.

Kementerian Kesehatan Republik Indonesia. (2015). Profil Kesehatan Jawa Timur 2015.

Khatoon R, Sachan B, Khan M, Srivastava J (2017). Impact Of School Health Education Program On Personal Hygiene Among School Children Of Lucknow District. Journal Of Family Medicine And Primary Care, 6(1): 97. Doi: 10.4103/2249-4863.214973.

Kurniasari AD, Nurhayati F (2017). Hubungan Antara Tingkat Pendidikan, Pekerjaan Dan Pendapatan Orang Tua Dengan Status Gizi Pada Siswa SD Hangtuah 6 Surabaya, 5 (2): 164-170.

Kurniawati L, Nurrochmah S, Katmawanti S (2017). Kedungkandang Kota Malang.

Larson E (1999). Skin Hygiene And Infection Prevention: More of The Same or Different Approaches?, Clinical Infectious Diseases, 29(5): 1287-1294. doi: 10.1086/313468.

Miranda W, Neto F, Barrozo L (2014). Socio-Economic and Environmental Effects Influencing the Development of Leprosy in Bahia, North-Eastern Brazil, Tropical Medicine and International Health, 19(12): 1504-1514. doi: 10.1111/tmi.12389.

Murto C, Chammartin F, Schwarz K, Cos- 
ta LMM, Kaplan C, Heukelbach J (2013). Patterns of Migration and Risks Associated with Leprosy among Migrants in Maranhão, Brazil. PLoS Neglected Tropical Diseases, 7(9). doi: 10.1371/journal.pntd.0002422.

Reibel F, Cambau E, Aubry A (2015). Update on the Epidemiology, Diagnosis, and Treatment of Leprosy, Me- decine et Maladies Infectieuses, 45(9): 383-393.

WHO (2016a) Global Leprosy Strategy 2016-2020.

(2016b) Leprosy: weekly epidemiological record, Septembre 2016, World Health Organisation Weekly epidemiological record, 91(35): 405-420. doi: 10.1186/1750-93782-15.Voir. 